\title{
Pengetahuan dan Sikap Perawat dalam Memenuhi Kebutuhan Psikologis dan Spiritual Klien Terminal
}

\author{
Yuke Kiran $^{1}$, Umi Sri Puspita Dewi ${ }^{2}$ \\ ${ }^{1,2}$ Akademi Keperawatan Rumah Sakit Dustira Cimahi \\ Email : ${ }^{1}$ kiranayuke55@gmail.com
}

\begin{abstract}
ABSTRAK
Pengetahuan dan sikap perawat dalam memenuhi kebutuhan psikologis dan spiritual klien terminal penting dikuasai oleh perawat dalam memberikan asuhan keperawatan. Kebutuhan klien pada stadium lanjut suatu penyakit, tidak hanya memerlukan perawatan secara fisik saja, tetapi memerlukan juga dukungan tentang kebutuhan psikologis dan spiritual. Tujuan dari penelitian ini untuk mengetahui hubungan antara pengetahuan dengan sikap perawat dalam memenuhi kebutuhan psikologis dan spiritual pada klien terminal. Metode penelitian yang digunakan deskriptif korelasi dengan pendekatan cross sectional. Populasi dalam penelitian ini adalah seluruh perawat pelaksana di Ruang III, Ruang X, Ruang XIII, dan ICU Rumah Sakit Tingkat II Dustira dengan sampel berjumlah 70 perawat. Teknik yang digunakan adalah total sampling.Terdapat dua variable yaitu pengetahuan dan sikap perawat. Metode pengumpulan data menggunakan kuesioner. Hasil uji validitas dan reliabilitas didapatkan 34 item valid. Analisis data dibagi menjadi dua tahapan, yaitu 1)univariat untuk melihat distribusi frekuensi; dan 2) bivariat untuk melihat hubungan. Hasil penelitian didapatkan bahwa hampir setengah responden (42,9\%) berpengetahuan baik, hampir setengah responden $(41,4 \%)$ berpengetahuan cukup, dan sebagian kecil responden $(15,7 \%)$ berpengetahuan kurang. Sebagian besar responden $(61,4 \%)$ memiliki sikap yang mendukung dan hampir setengahnya responden $(38,6 \%)$ memiliki sikap yang tidak mendukung. Hasil chi-square test diperoleh p- value 0,798 $>\alpha 0,05$ yang berarti tidak terdapat hubungan antara pengetahuan dengan sikap perawat dalam memenuhi kebutuhan psikologis dan spiritual. Bagi perawat diharapkan dapat memberikan asuhan keperawatan yang optimal kepada klien dengan penyakit terminal terutama dalam hal psikologis dan spiritual dengan cara melibatkan keluarga. Untuk meningkatkan pengetahuan, perawat bisa mengikuti in service training atau seminar minimal sebanyak 3 kali.
\end{abstract}

Kata kunci: Kebutuhan Psikologis dan Spiritual, Pengetahuan, Sikap.

\section{ABSTRACT}

Knowledge and attitudes of nurses to meet the psychological and spiritual needs of the client important terminal controlled by nurses in providing nursing care. The client needs at an advanced stage of disease, treatment requires not only physically alone, but requires also the support of the needs psychological and spiritual. The aim of this study was to determine the relationship between knowledge and attitude of nurses to meet the psychological and spiritual needs of the clients of the research terminal. This study uses descriptive correlation with a cross-sectional approach in this study are all nurses in Space III, Space X, XIII space, and ICU Hospital Level II Dustira with the sample amounted to 70 nurses.Tehnik used is total sampling.Terdapat two variables, namely knowledge and the attitude of nurses. Methods of data collection using the questionnaire. Validity and reliability of test results obtained 34 valid items. Analysis of the data is divided into two stages, namely to see the univariate and bivariate frequency distribution to see the connection. The research found that nearly half of respondents (42.9\%) knowledgeable good, almost half of respondents $(41.4 \%)$ knowledgeable enough, and a small proportion of respondents $(15.7 \%)$ less knowledgeable. Most respondents (61.4\%) have a supportive attitude and almost half of the respondents (38.6\%) had the attitude that does not support. Chi-square result test was obtained p-value 0.798> $\alpha 0.05$, which 
means there is no correlation between knowledge and attitude of nurses in psychological and spiritual needs. For nurses is expected to provide optimum nursing care to clients with terminal illnesses, especially in terms of psychological and spiritual in a way involving family. To improve knowledge, nurses can follow in-service training or seminar training at least 3 times.

Keywords: Psychological and Spiritual Needs, Knowledge, Attitude.

\section{PENDAHULUAN}

Pengetahuan dan sikap yang benar dalam memenuhi kebutuhan psikologis dan spiritual klien terminal sangat penting dikuasai oleh perawat professional dalam memberikan asuhan keperawatan, sehingga tujuan dalam memberikan asuhan keperawatan yang holistik kepada klien tercapai. Hal ini disebabkan karena kebutuhan klien pada suatu penyakit stadium lanjut tidak hanya berupa perawatan secara fisik, namun juga perlu adanya dukungan terhadap baik kebutuhan psikologis, sosial maupun spiritual, dimana kebutuhan tersebut sangat penting agar klien merasakan ketenangan dan kenyamanan dalam menghadapi penyakit yang sedang di deritanya. Berkaitan dengan hal tersebut, peran perawat dalam memberikan dukungan asuhan keperawatan sangat dibutuhkan.

Salah satu peran perawat dalam menangani klien dengan keadaan terminal yaitu memberikan suatu asuhan keperawatan untuk membantu klien menjalani sisa hidupnya dalam keadaan yang seoptimal mungkin. Perawat harus mempunyai pengetahuan yang dapat diberikan kepada klien diantaranya mempelajari respons klien terhadap penerimaan penyakitnya secara mendalam. Menurut Kubler - Ross, 2009, respon individu sebelum menerima kondisinya dibagi kedalam lima fase, yaitu penyangkalan dan isolasi, marah, tawar menawar, depresi, dan terakhir penerimaan.

$$
\text { Menurut Notoatmojo, } 2010 .
$$

Pengetahuan merupakan domain yang sangat penting untuk terbentuknya tindakan dan memiliki beberapa tingkatan pengetahuan diantaranya tahu (know), memahami (comprehension) dan aplikasi (application). Begitu pula dengan sikap menurut Wahit, dkk. (2007) menjelaskan bahwa sikap merupakan reaksi atau respons seseorang terhadap stimulus atau objek. Sikap terdiri dari 4 tingkatan yaitu dapat menerima (receiving), mampu merespon (responding), dan menghargai (valuing) serta bertanggung jawab (responsible). Perilaku manusia sangat kompleks dan mempunyai ruang lingkup yang luas. Terbentuknya suatu perilaku baru terutama pada orang dewasa dimulai dari domain kognitif, dalam arti subjek terlebih dahulu mengetahui terhadap stimulus yang berupa materi atau obyek luarnya sehingga menimbulkan pengetahuan dan sikap baru pada subyek tersebut.

Sikap juga penting ditunjukkan oleh seorang perawat ketika akan memberikan asuhan keperawatan kepada klien terminal. Perawat seharusnya dapat memberikan semua perawatan yang masih bisa diberikan kepada klien, baik kebutuhan psikologis dan spiritual.

Pentingnya bimbingan spiritual dalam kesehatan telah menjadi ketetapan World Health Organization (WHO), 1984 yang menyatakan bahwa aspek agama (spiritual) merupakan salah satu unsur dari pengertian kesehatan seutuhnya. Perawat memiliki peran untuk memenuhi kebutuhan biologis, sosiologis, dan spiritual klien karena peran perawat yang komprehensif tersebut pasien senantiasa mendudukan paerawat dalam tugas mulia mengantarkan pasien diakhir hayatnya. Akan tetapi kebutuhan tersebut seringkali dianggap tidak penting oleh perawat.

Banyak perawat merasa tidak nyaman atau kurang siap dalam memberikan asuhan spiritual sehingga sering menghindari pembahasan mengenai isu spiritual. Walaupun kebutuhan spiritual manfaatnya sangat besar, alasan keraguan dan 
ketidakpastian personal dapat memunculkan perasaan tidak mampu membantu klien dalam memberikan asuhan spiritual.

Kondisi terminal merupakan suatu proses yang progesif menuju kematian berjalan melalui suatu tahapan proses penurunan fisik, psikososial dan spiritual bagi individu. Berbagai penelitian telah dilakukan tentang bagaimana perilaku klien terminal. Bila mereka atau keluarganya telah diberitahu bahwa penyakit yang dideritanya tidak dapat disembuhkan lagi, dalam menghadapi hal tersebut perawat harus mampu memberikan perawatan yang manusiawi, dengan memperhatikan aspek biologis, psikologis dan spiritual. Perawat juga perlu dibekali pengetahuan tentang bagaimana cara menghadapi klien dan keluarganya saat fase isolasi, fase depresi, fase amarah, dan fase penerimaan. Dalam setiap fase ini tenaga keperawatan patut mengantisipasi perilakunya, agar tetap dapat memberikan pelayanan yang optimal.

Rumah Sakit Tk.II Dustira adalah rumah sakit yang berada di Jl. Dr. Dustira no 1 Kota Cimahi dan merupakan rumah sakit kebanggaan prajurit, sipil TNI dan keluarganya, Rumah Sakit Dustira berada di wilayah Kodam III Siliwangi dan sekaligus sebagai Rumah Sakit rujukan tertinggi di lingkungan Angkatan Darat. karena mampu mengupayakan pelayanan kesehatan kuratif dan rehabilitatif yang terpadu dengan pelaksanaan kegiatan kesehatan promotif dan preventif. Rumah Sakit ini juga telah dilengkapi sarana dan prasarana yang cukup memadai, terutama untuk perawatan klien terminal. Berdasarkan data yang diperoleh dari Informasi Kesehatan Rumah Sakit Tingkat II Dustira, diketahui bahwa tiga bulan terakhir, sejak bulan Januari hingga Maret terdapat 772 orang dengan penyakit terminal yang dirawat di ruang III, ruang $\mathrm{X}$, ruang XIII, dan ruang ICU. Dengan rincian sebanyak 224 orang dirawat di ruang III, 100 orang dirawat di ruang $\mathrm{X}, 387$ orang dirawat di ruang XIII, dan 61 orang dirawat di ruang
ICU. Jumlah terbanyak klien dengan kondisi terminal terdapat di ruang XIII sebanyak 387 orang.

Berdasarkan studi pendahuluan yang telah dilakukan peneliti pada sepuluh orang perawat, enam orang perawat mengatakan bahwa mereka mengetahui tentang perawatan klien terminal yang berkaitan dalam memenuhi kebutuhan psikologis dan spiritual, namun tentang dukungan spiritual belum mengaplikasikannya. Mereka juga mengatakan sangat penting untuk memenuhi kebutuhan psikologis dan spiritual klien terminal, namun mereka belum siap melaksanakannya karena mereka lebih mengutamakan kebutuhan fisiologis klien. Empat orang perawat lainnya mengatakan mereka mengetahui dan sudah mengaplikasikan perawatan yang harus diberikan pada klien terminal terutama dalam memenuhi kebutuhan psikologis maupun spiritual, karena kebutuhan psikologis dan spiritual pada klien terminal itu sangat diperlukan untuk memberikan ketenangan, kenyamanan dan kesiapan dalam menghadapi penyakitnya. Oleh karena itu apabila klien sudah dinyatakan dalam keadaan terminal, perlu adanya pendampingan baik dari perawat maupun dari pemuka agama sesuai dengan keyakinan yang dimilikinya. Dalam memberikan asuhan keperawatan selain memenuhi kebutuhan fisiologis, mereka juga harus mendapatkan perawatan dalam hal pemenuhan kebutuhan psikologis dan spiritual.

Dalam memenuhi kebutuhan terhadap dukungan psikologis dan spiritual pada klien dengan penyakit terminal, diharapkan perawat dapat memberikan asuhan keperawatan yang holistik sehingga klien dan keluarga merasa puas dan dapat menerima kenyataan.

Berdasarkan permasalahan tersebut, penulis tertarik untuk melakukan penelitian tentang Hubungan Pengetahuan dengan Sikap Perawat Dalam Memenuhi Kebutuhan Psikologis dan Spiritual Pada Klien Terminal di Rumah Sakit Tingkat II Dustira Cimahi. 


\section{METODE}

Berdasarkan tujuan penelitian, maka desain penelitian yang digunakan penelitian deskriptif korelasi, untuk mengetahui hubungan pengetahuan dan sikap perawat dalam memenuhi kebutuhan psikologi dan spiritual pada pasien terminal dengan rancangan penelitian cross sectional. Populasi dalam penelitian ini adalah seluruh perawat pelaksana di ruang III, X, XIII, dan ICU Rumah Sakit Tingkat II Dustira sejumlah 70 orang perawat. Data ini diperoleh pada bulan Maret 2013. Teknik sampling yang digunakan dalam penelitian ini adalah total sampling, dimana seluruh anggota populasi dijadikan sampel.

Kemudian pemilihan sampel dilakukan berdasarkan tujuan dan kriteria yang sudah ditentukan yaitu kriteria inklusi yaitu seluruh perawat pelaksana ruang III, X, XIII, ICU dan bersedia menjadi sampel penelitian. Dalam penelitian ini terdapat variabel independent berupa tingkat pengetahuan dan variabel dependent berupa sikap perawat dalam memenuhi kebutuhan psikologi dan spiritual pada pasien terminal. Hasil hypotesa bila $\mathrm{H}_{0}$ : tidak ada hubungan yang bermakna, $\mathrm{H}_{1}$ : terdapat hubungan yang bermakna. Instrumen yang digunakan dalam penelitian ini adalah angket tertutup (kuesioner). Dengan metoda wawancara langsung dengan perawat pelaksana ruangan yang terpilih dalam penelitian. Kuesioner yang ada terdiri dari dua bagian yaitu Instrumen penelitian untuk mengukur pengetahuan perawat dalam memenuhi kebutuhan psikologis dan spiritual klien terminal dengan menggunakan pertanyaan pilihan berjumlah 19 pertanyaan berganda. Responden menjawab dengan cara memberi tanda silang (X) pada salah satu pilihan jawaban yang dianggap benar, dengan tiga pilihan jawaban (A, B, dan C). Jawaban benar diberi nilai 1 , jawaban salah diberi nilai 0 . Untuk mengukur sikap perawat dalam memenuhi kebutuhan psikologis dan spiritual klien terminal dengan menggunakan pernyataan sebanyak 15 pernyataan dengan menggunakan skala Likert. Responden menjawab dengan cara memberi tanda cek $(\sqrt{ })$ pada salah satu pilihan jawaban yang dianggap benar, dengan lima pilihan jawaban (Sangat Setuju, Setuju, Kurang Setuju, Tidak Setuju, Sangat Tidak Setuju).

Instrumen yang digunakan dilakukan uji validitas sebanyak 34 pertanyaan dan dinyatakan ke 34 pertanyaan seluruhnya valid. Uji validitas telah dilaksanakan pada bulan Mei tahun 2013 di Rumah Sakit Dr. Salamun pada 20 orang perawat karena dianggap memiliki karakteristik yang sama dengan Rumah Sakit Tingkat II Dustira Cimahi. Data diolah dengan menggunakan analisis univariat dan bivariat. Hasil penelitian disajikan dengan menggunakan tabel distribusi frekuensi dan prosentase (Riyanto, 2011). Analisis bivariat untuk membuktikan adanya hubungan yang bermakna antara variabel independent dengan variabel dependent. Uji statistik dilakukan dengan metode Chi -squere atau Chi Kuadrat karena data yang diolah berbentuk data katagorik dengan kriteria pengujian adalah bila $p$-value $<\alpha=0,05$ maka artinya ada hubungan yang bermakna secara statistik, tetapi bila $\mathrm{p}$-value $>\alpha=0,05$ maka berarti tidak signifikan atau tidak ada hubungan yang bermakna secara statistik.

HASIL DAN PEMBAHASAN

$\begin{array}{lll}\text { Distribusi Frekuensi } & \text { Responden } \\ \text { Berdasarkan Pengetahuan } & \end{array}$

Tabel 1. Distribusi Frekuensi Pengetahuan Perawat di Ruang Perawatan III, Ruang Perawatan X, Ruang Perawatan XIII, dan ICU Tahun 2013

\begin{tabular}{lcc}
\hline Pengetahuan & Frek & Presentase \\
\hline Baik & 30 & $42,9 \%$ \\
Cukup & 29 & $41,4 \%$ \\
Kurang & 11 & $15,7 \%$ \\
\hline Total & $\mathbf{7 0}$ & $\mathbf{1 0 0} \%$ \\
\hline
\end{tabular}

Tabel 1 menggambarkan bahwa dari 70 orang responden hampir setengah dari 
responden $(42,9 \%)$ memiliki pengetahuan yang baik tentang pemenuhan kebutuhan psikologis dan spiritual klien terminal. Hampir setengah dari responden ( 41,4\%) memiliki pengetahuan yang cukup. Sebagian kecil dari responden ( $15,7 \%)$ memiliki pengetahuan yang kurang.

Tabel 2. Distribusi Frekuensi Sikap Perawat di Ruang Perawatan III, Ruang Perawatan X, Ruang Perawatan XIII, dan ICU Tahun 2013

\begin{tabular}{lcc}
\hline Sikap & Frekuensi & Presentase \\
\hline Mendukung & 43 & $61,4 \%$ \\
Tidak mendukung & 27 & $38,6 \%$ \\
\hline Total & $\mathbf{7 0}$ & $\mathbf{1 0 0 \%}$ \\
\hline
\end{tabular}

\section{Distribusi Frekuensi Responden Berdasarkan Sikap}

Tabel 2 menunjukkan bahwa dari 70 responden, sebagian besar dari responden (61,4 \%) memiliki sikap yang mendukung tentang pemenuhan kebutuhan psikologis dan spiritual klien terminal dan hampir setengahnya dari responden $(38,6 \%)$ memiliki sikap yang tidak mendukung.

\section{Tabel 3. Analisis Hubungan antara Pengetahuan Dengan Sikap Perawat Dalam memenuhi Kebutuhan Psikologis dan Spiritual Pada klien Terminal di Ruang Perawatan III, Ruang Perawatan X, Ruang Perawatan XIII, dan ICU Tahun 2013}

\begin{tabular}{|c|c|c|c|c|c|c|c|}
\hline \multirow{3}{*}{$\begin{array}{c}\text { Pengetah } \\
\text { uan } \\
\text { Perawat }\end{array}$} & \multicolumn{4}{|c|}{ Sikap Perawat } & & \multirow[t]{3}{*}{ Total } & \multirow[t]{3}{*}{ P Value } \\
\hline & \multirow{2}{*}{\multicolumn{2}{|c|}{$\begin{array}{c}\text { Menduku } \\
\text { ng }\end{array}$}} & \multirow{2}{*}{\multicolumn{2}{|c|}{$\begin{array}{c}\text { Tidak } \\
\text { Menduku } \\
\text { ng }\end{array}$}} & & & \\
\hline & & & & & & & \\
\hline & $\mathrm{n}$ & $\%$ & $\mathrm{n}$ & $\%$ & $\mathrm{n}$ & $\%$ & \\
\hline Baik & 18 & 60,0 & 12 & 40,0 & 30 & 100 & 0,798 \\
\hline Cukup & 19 & 65,5 & 10 & 34,5 & 29 & 100 & \\
\hline Kurang & 6 & 54,4 & 5 & 45,5 & 11 & 100 & \\
\hline Total & 43 & 61,4 & 27 & 38,6 & 70 & 100 & \\
\hline
\end{tabular}

Berdasarkan tabel 3 sebagian besar dari respoden yang memiliki pengetahuan cukup $(65,5 \%)$ memiliki sikap yang mendukung dalam memenuhi kebutuhan psikologis dan spiritual klien terminal. Hampir setengah dari responden yang memiliki pengetahuan kurang
$(45,5 \%)$ memiliki sikap yang tidak mendukung. Dari analisis hubungan antara pengetahuan dengan sikap, didapatkan $p$ value $=0,798>\alpha=0,05$ sehingga Ho gagal ditolak, ini menunjukkan bahwa tidak terdapat hubungan antara pengetahuan dengan sikap perawat dalam memenuhi kebutuhan psikologis dan spiritual klien terminal.

\section{PEMBAHASAN}

\section{Pengetahuan Perawat Tentang Pemenuhan Kebutuhan Psikologis dan Spiritual Klien Terminal}

Menurut Soekanto (2003) Pengetahuan adalah kesan di dalam pikiran manusia sebagai hasil penggunaan panca inderanya. Dengan adanya kemauan perawat untuk mengingat suatu hal termasuk mengingat kembali kejadian yang pernah dialami dan melakukan pengamatan terhadap objek tertentu maka pengetahuan perawat akan bertambah dan pengetahuan perawat menjadi lebih baik.

Berdasarkan hasil analisis univariat pada tabel 1 didapatkan data bahwa hampir setengah dari responden (42,9 \%) berpengetahuan baik tentang pemenuhan kebutuhan psikologis dan spiritual klien terminal. Hasil dari penelitian ini sejalan dengan penelitian yang dilakukan oleh Iqbal (2010) dengan hasil yaitu hampir setengah dari perawat $(48,9 \%)$ berpengetahuan baik tentang pemberian asuhan keperawatan pada pasien terinfeksi HIV/AIDS.

Menurut Nursalam (2003), tidak dapat dipungkiri bahwa semakin tinggi pendidikan seseorang semakin mudah pula menerima informasi. Hal ini terlihat pada rata - rata pendidikan perawat di Rumah Sakit Tingkat II Dustira yaitu D3. Selain pendidikan, umur juga mempengaruhi seseorang dalam menerima informasi. Menurut Wawan (2010) semakin cukup umur, tingkat kematangan dan kekuatan seseorang akan lebih matang dalam berfikir. Terbukti pada rata-rata umur perawat 
yang menjadi responden yaitu diatas 22 tahun.

Dengan adanya kemauan perawat untuk mengingat suatu hal termasuk mengingat kembali kejadian yang pernah dialami dan melakukan pengamatan terhadap objek tertentu maka pengetahuan perawat akan bertambah dan pengetahuan perawat menjadi lebih baik. Pengetahuan merupakan hasil mengingat suatu hal, termasuk mengingat kembali kejadian yang pernah dialami baik secara sengaja maupun tidak sengaja dan ini terjadi setelah orang melakukan pengamatan terhadap suatu objek tertentu.

Menurut peneliti, pengetahuan perawat yang baik dipengaruhi oleh faktor internal yang terdapat dalam diri perawat itu sendiri. Perawat mengetahui, memahami dan mengaplikasikan ilmu yang telah mereka dapatkan. Pengetahuan perawat yang baik ini memungkinkan perawat dapat memberikan informasi yang dibutuhkan oleh klien dan keluarganya sesuai dengan perannya sebagai sumber informasi (consultant). Keinginan perawat untuk terus berkembang dan terus berusaha memberikan asuhan keperawatan yang seoptimal mungkin, dapat memotivasi perawat untuk terus meningkatkan pengetahuannya, dalam hal ini pengetahuan tentang pemenuhan kebutuhan psikologis dan spiritual klien terminal.

\section{Sikap Perawat Tentang Pemenuhan Kebutuhan Psikologis dan Spiritual Klien Terminal}

Sikap adalah respon tertutup seseorang terhadap stimulus atau objek tertentu, yang sudah melibatkan faktor pendapat dan emosi yang bersangkutan. Sikap merupakan kesiapan atau kesediaan untuk bertindak, dan bukan merupakan pelaksanaan motif tertentu. Dalam kata lain, sikap belum merupakan tindakan (reaksi terbuka) atau aktivitas. Akan tetapi merupakan predisposisi perilaku (tindakan), atau reaksi tertutup. (Notoatmodjo, 2010).
Berdasarkan hasil penelitian bahwa sebagian besar dari responden $(61,4 \%)$ memiliki sikap yang mendukung dalam memenuhi kebutuhan psikologis dan spiritual klien terminal. Sikap mendukung yang ditunjukkan berhubungan dengan faktor faktor yang mempengaruhi sikap seperti yang diutarakan oleh Wawan (2010). Pertama, pengaruh orang lain yang dianggap penting. Pada umumnya individu cenderung memiliki sikap yang konformis atau searah dengan sikap seseorang yang dianggap penting. Kedua, pengaruh kebudayaan, tanpa disadari kebudayaan telah menanamkan garis pengarah sikap kita terhadap berbagai masalah. Dan yang terakhir yaitu faktor emosional, terkadang suatu bentuk sikap merupakan pernyataan yang didasari emosi.

Terbentuknya sikap positif dari perawat dapat dipengaruhi oleh interaksi antar sesama perawat, karena sikap terbentuk dengan interaksi terjadi saling tukar informasi mengenai hal yang berhubungan dengan pelaksanaan asuhan keperawatan. Perawat mau dan memperhatikan kebutuhan klien, mengerjakan dan menyelesaikan yang diberikan serta mengajak orang lain untuk mengerjakan atau mendiskusikan suatu masalah.

Hal ini sesuai dengan teori tingkatan sikap yang diutarakan oleh Notoatmodjo (2007) yaitu sikap memiliki berbagai tingkatan, yang pertama menerima (receiving). Kedua merespon (responding), ketiga menghargai (valuing) dan terakhir bertanggung jawab (responsible). Pada dasarnya sikap perawat yang ditunjukkan sudah mencapai pada tingkatan bertanggung jawab (responsible) yaitu bertanggung jawab atas segala yang dipilihnya dengan segala resiko yang mungkin akan terjadi.

Hubungan Antara Pengetahuan Dengan Sikap Perawat Dalam Memenuhi Kebutuhan Psikologis Dan Spiritual Pada Klien Terminal Di Rumah Sakit Tingkat II Dustira Cimahi. 
Berdasarkan hasil uji korelasi yang dilakukan, dengan ( $\mathrm{p}$ value $=0,798>\alpha=$ 0,05) menunjukkan Ho gagal ditolak atau tidak ada hubungan antara pengetahuan dengan sikap perawat dalam memenuhi kebutuhan psikologis dan spiritual pada klien terminal di Rumah Sakit Tingkat II Dustira Cimahi. Hal ini dapat dijelaskan bahwa banyak faktor yang mempengaruhi pembentukan sikap seseorang. Sebagaimana diketahui bahwa sikap tidak dibawa sejak lahir, tetapi dipelajari dan dibentuk berdasarkan pengalaman individu sepanjang perkembangan selama hidupnya. Pada individu sebagai makhluk sosial, pembentukan sikap tidak lepas dari pengaruh interaksi (eksternal). Di samping itu, manusia juga sebagai makhluk individual sehingga apa yang datang dari dalam dirinya, juga memengaruhi pembentukan sikap.

Seorang perawat yang memiliki pengetahuan yang baik, belum tentu memiliki sikap yang baik pula. Hal ini sejalan dengan hasil penelitian Sulastri (2015) yang menunjukkan tidak ada hubungan antara pengetahuan dengan perilaku kesehatan seorang individu. Hal ini disebabkan karena banyak faktor yang mempengaruhi pengetahuan dan sikap seseorang. Dari beberapa faktor yang mempengaruhi, pengetahuan, pendidikan, umur dan lingkungan adalah yang paling berperan. Sebagaimana diketahui semakin tinggi pendidikan perawat dan semakin matang umur perawat, hal ini dapat dijelaskan bahwa semakin matang umur perawat, maka semakin mudah untuk menerima informasi, semakin banyak pengalaman yang ia dapatkan, maka semakin banyak ilmu yang ia dapatkan. Sementara itu, lingkungan juga dapat mempengaruhi perkembangan dari pengetahuan dan sikap perawat dalam memberikan asuhan keperawatan. Faktorfaktor pemungkin (enabling factors) yang terwujud dalam lingkungan, tersedia atau tidak tersedianya fasilitas-fasilitas yang mempengaruhi pembentukan sikap dari seorang perawat.

Berdasarkan hasil pada tabel 3, meskipun pengetahuan perawat tentang pemenuhan kebutuhan psikologis dan spiritual klien terminal mayoritas pada kategori baik, namun sikap perawat dalam memenuhi kebutuhan psikologis dan spiritual masuk dalam kategori mendukung. Tetapi persentase pada responden dengan pengetahuan yang cukup memiliki sikap yang mendukung lebih tinggi yaitu $65,5 \%$ dibandingkan dengan responden yang pengetahuannya baik sebanyak $60,0 \%$. Hal ini menunjukkan bahwa perawat yang pengetahuannya baik, belum tentu sikapnya mendukung.

Sejalan dengan teori Notoatmodjo (2010) pengetahuan terdiri dari 6 tingkatan domain kognitif. Tingkatan ketiga dari domain kognitif tersebut setelah tahu dan memahami adalah aplikasi. Hal ini berarti bahwa perawat yang memahami tentang pentingnya pemenuhan kebutuhan psikologis dan spiritual pada klien terminal, seharusnya dapat mengaplikasikannya. Peneliti berasumsi bahwa sebelum domain pengetahuan seorang individu sampai pada tahap tingkat aplikasi, ini memungkinkan seseorang tersebut sudah sampai pada domain tahu dan memahami, namun belum mampu mengaplikasikan sepenuhnya sesuatu tersebut. Dalam hal ini mengaplikasikan pengetahuan tentang pemenuhan kebutuhan psikologis dan spiritual diwujudkan dalam bentuk sikap dan perilaku.

Tugas utama seorang perawat adalah mengidentifikasi perubahan pola interaksi klien terhadap keadaan sehat sakitnya. Perawat dapat memberikan pelayanan keperawatan secara langsung dan tidak langsung kepada klien, dengan menggunakan proses keperawatan. Perawat juga dapat berkolaborasi dengan keluarga atau tim kesehatan klien untuk menentukan rencana ataupun pelaksanaan asuhan keperawatan kepada klien. Hal ini sesuai dengan yang dikemukakan oleh Kusnanto (2004) tentang 
peran perawat yaitu sebagai pemberi asuhan keperawatan (care giver), pembela klien (client advocate), pemberi bimbingan (counselor), pendidik klien (educator), kolaborasi (collaborator), pembaru (change agent), dan sumber informasi (consultant).

\section{SIMPULAN}

Berdasarkan uraian dan analisis yang telah dilakukan pada masalah pemenuhan dukungan psikologi dan spiritual pada klien terminal di Rumah Sakit Tingkat II Dustira Cimahi pada tahun 2013, maka hasil penelitian ini dapat disimpulkan bahwa hampir setengah dari responden (42,9 \%) memiliki pengetahuan yang baik dalam memenuhi kebutuhan psikologis dan spiritual pada klien terminal, sebagian besar responden $(61,4 \%)$ sikapnya mendukung dalam memenuhi kebutuhan psikologis dan spiritual pada klien terminal. Hasil perhitungan statistic menunjukkan tidak terdapat hubungan antara pengetahuan dengan sikap perawat dalam memenuhi kebutuhan psikologis dengan nilai $\mathrm{P}$ value $=0,798>\alpha=$ 0,05 .

\section{SARAN}

Penelitian ini menghasilkan saran bagi Perawat untuk dapat memberikan asuhan keperawatan yang optimal kepada klien dengan penyakit terminal terutama dalam memberikan dukungan psikologis dan spiritualhal psikologis dan spiritual dengan cara melibatkan keluarga dalam pemenuhan kebutuhan psikologis dan spiritual. Bagi perawat yang pengetahuannya baik, diharapkan dapat pengetahuannya cukup dan kurang diharapkan meningkatkan pengetahuannya dengan cara lebih sering mengikuti workshop atau seminar yang berkaitan dengan pemenuhan kebutuhan psikologis dan spiritual pada klien terminal serta mengikut incervice training minimal lebih dari tiga kali dan perilaku yang positif dengan cara memberikan asuhan keperawatan yang optimal kepada klien, terutama pemenuhan kebutuhan psikologis dan spiritual pada klien terminal. Saran untuk Rumah Sakit diharapkan dapat mengambil kebijakan yang mendukung pengetahuan dan sikap perawat dalam memenuhi kebutuhan psikologis dan spiritual pada klien terminal, seperti seminar tentang pemenuhan kebutuhan psikologis dan spiritual pada klien terminal dan mengadakan in-service training minimal sebanyak satu bulan sekali.

\section{DAFTAR PUSTAKA}

Iqbal, M. 2010, Gambaran Tingkat

Pengetahuan dan Perilaku Perawat

Dalam Pemberian Asuhan

Keperawatan Pada Pasien Terinfeksi HIV/AIDS.

http://publikasi.umy.ac.id/index.php./ps $\mathrm{ik} /$ article/viewFile/2613/1652 diunduh tanggal 8 Agustus 2013

Kusnanto. 2004. Pengantar Profesi dan Praktik Keperawatan Profesional. Jakarta: EGC

Nursalam. 2003. Konsep dan Penerapan Metodologi Penelitian Ilmu Keperawatan Edisi 1. Jakarta : Salemba Medika

Notoatmodjo, S. 2010. Ilmu Perilaku. Jakarta: Rineka cipta 2010. Ilmu Perilaku. Jakarta: Rineka cipta

Riyanto, Agus. 2011. Aplikasi Metodologi Penelitian Kesehatan. Yogyakarta: Nuha Medika

Sulastri, A. 2015. Hubungan Pengetahuan Sains Remaja di Bandung terhadap Perilaku Sehatnya. Jurnal Keperawatan Aisyiah No.1(2). Bandung: STIKES Aisyiah

Wawan, A. 2010. Teori dan Pengukuran Pengetahuan, Sikap, dan Perilaku Manusia. Yogyakarta : Nuha Medika 